\title{
Polydactyly: A study of a four generation Egyptian family
}

\author{
Samah Mohammed Mahmoud Abozaid \\ Department of Anatomy, Faculty of medicine, Minia University, Minia, Egypt
}

Correspondence Author: Samah Mohammed Mahmoud Abozaid, Department of Anatomy, Faculty of medicine, Minia University, Minia, Egypt E-mail: samah.abozaid@mu.edu.eg

Received date: 1 December 2018, Accepted date: 10 December 2018, Online date: 29 January 2019

Copyright: (C) 2019 Samah Mohammed Mahmoud Abozaid, This is an open-access article distributed under the terms of the Creative Commons Attribution License, which permits unrestricted use, distribution, and reproduction in any medium, provided the original author and source are credited.

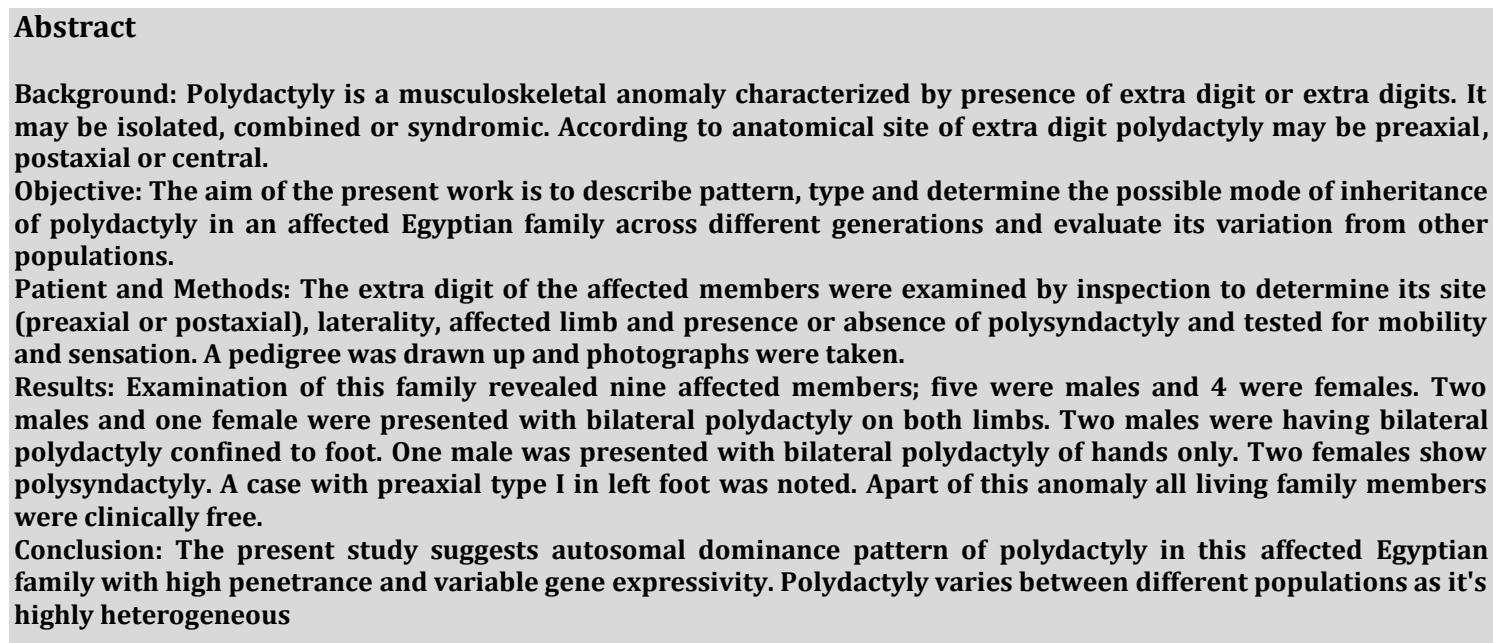

Key words: polydactyly, polysyndactyly, autosomal dominance, Egyptian family

\section{INTRODUCTION}

Polydactyly is a musculoskeletal anomaly characterized by the presence of an extra digit, digits or part of a digit in hand or foot or both. Abnormally placed tissue may be the only finding (Zhou et al., 2004).

Polydactyly may be an isolated anomaly (no other associated anomalies), combined (with another musculoskeletal anomaly) or syndromic (presence of associated non-skeletal anomaly) (Castilla et al., 1998). Sporadic type of polydactyly is diagnosed if present in only one generation of a family with no previous history of this anomaly (Karaaslan et al., 2003).

Polydactyly is presented in different patterns (Watson and Hennrikus, 1997). According to anatomical position of the extra digit, polydactyly may be preaxial (radial or tibial), postaxial (ulnar or fibular) or central polydactyly (presence of duplicated second, third, or fourth digits) (Haber et al., 2007). Crossed polydactyly is defined as presence of preaxial polydactyly of hands and postaxial of feet, or the reverse (Hosalkar et al., 1999). When there is complete or incomplete fusion between the duplicated digits, this is classified as polysyndactyly (Nogami, 1986).

Gene mutation is responsible for Isolated postaxial polydactyly which is inherited as an autosomal dominance with incomplete penetrance (Bromley et al., 2000) and variable expressivity as it may skip a generation (Castilla et al., 1973). More than one gene has been identified to be associated with isolated postaxial polydactyly (Bromley et al., 2000).

The variable presentation of isolated polydactyly may be due to other developmental or stochastic processes affecting the development of the disease (Ying et al., 2016).

Hand postaxial polydactyly trait differs from that of foot in frequency and association with other malformations as Hand postaxial polydactyly has higher frequency (75\%) than that of foot (15\%), and low occurrence with other anomalies (7\% vs $15 \%)$. Occurrence of both hand and foot postaxial polydactyly is less frequent (10\%) and has a high association with other anomalies (23\%) (Castilla et al., 1997). 
Postaxial polydactyly (PAP) is the most common congenital hand deformity. Prevalence rate of PAP is $1-2 / 1000$ live births with some difference in ethnic groups (Zhou et al., 2004). Preaxial polydactyly occurrence is low (1 in every 3,000 live births) and more common in Asian populations (Niha, 2017).

Postaxial polydactyly is clinically classified into type A and type B. Type A is presented with fully formed extra digit with bone, neural tissue either functioning or nonfunctioning and articulates with the fifth (or sixth) metacarpal or metatarsal bones. Type B is presented with hypoplastic digit known as pedunculated post minimi (Temtamy, and McKusick, 1978).

Both type A and type B polydactyly are considered different traits and involve different loci. Type B PAP is commonly associated with isolated familial PAP (Watson and Hennrikus, 1997).

An autosomal dominance (AD) inheritance pattern has been described for Indian and Turkish families with polydactyly (Koçer et al., 2002 and Kucheria et al., 1981).

Preaxial polydactyly has a variable presentation from radial skin vestige to complete duplication (Niha, 2017).

Type and incidence of polydactyly differ from one population to other. Higher incidence of PAP is seen in African people at 10.7 of 1000 live births and twice as common in males compared to females (Rittler et al., 2001) followed by Asian populations with incidence rate of 2.5 of 1000 live births and that of Caucasians is 1.6 of 1000 live births in (Rittler et al., 2001). On the other hand pre-axial polydactyly is common in Asian populations (Neglian, 2013) and it is non familial, and usually present in just one side of the limb (Stevenson et al., 1993). Central polydactyly is rare in all populations and occurs with syndromes (Neglian, 2013). This geographical and racial difference variable presentation of extra digit may be due to hereditary factor (Stevenson et al., 1993). However, the cellular and genetic mechanisms that control the development of digits in number and identity are deficient (Talamillo et al., 2005).

The aim of the present work was to determine the mode of inheritance, the type, pattern of involvement of polydactyly in an affected Egyptian family across different generations of this family and its variation from other populations and discuss possible causative genes. To the best of our knowledge this is the first study concerned with describing type, pattern and mode of inheritance of polydactyly running in an Egyptian family.

\section{SUBJECTS AND METHODS}

An Egyptian family of 24 family members across 4 generations with 9 affected members with polydactyly were investigated. There were no other apparent congenital malformations in any of the family members

All available family members were evaluated clinically to rule out other apparent congenital malformations. Their medical history was free except for one female case died from breast cancer and an infant died from strangulated inguinal hernia. Photographs of the available affected members were taken after informed consent.

Detailed history including age, gender, parental consanguinity, number of pregnancies, twin pregnancy, abortion, and family history of other malformations were taken and recorded.

Parental consanguinity was defined as consanguineous marriage between relatives in any degree.

The extra digit was assessed for sensation, palpated for consistency soft or hard (bony) and tested for presence of any movement. Related structures as nail and skin crease were inspected for associated abnormalities.

Polydactyly pattern was at first diagnosed by its presence in hand or foot, right side, left side or both.

Polydactyly type was classified into postaxial, preaxial and central according to anatomical site of the extra digit (Temtamy and McKusick, 1978). PAP was further subdivided into type A and B. In type A the extra digit is well developed in type B the extra digit is atrophied. Preaxial type was subdivided into four types. Type I: if there is duplication of one part or more of biphalangeal thumb/hallux. Type II: if there is an extra middle phalanx in thumb/hallux. Type III: if there is duplication of index finger. Type IV if thumb/hallux is either broader, bifid or with lateral deviation of distal phalanx (Niha, 2017).

A pedigree was drawn up for this family using standard symbols.

Photographs were the means for data recording.

\section{STATISTICAL ANALYSIS}

The qualitative variables were analyzed using SPSS statistical package version 20 and described by number (percent or ratio). Data were presented with tables.

\section{RESULTS}

The pedigree of affected family members (Fig. 1) is showing different types and patterns of inheritance of polydactyly regarding sex and generation. 
Citation: Samah Mohammed Mahmoud Abozaid, Polydactyly: A study of a four generation Egyptian family. Australian Journal of Basic and Applied Sciences, 13(1): 104-111. DOI: 10.22587/ajbas.2019.13.1.13

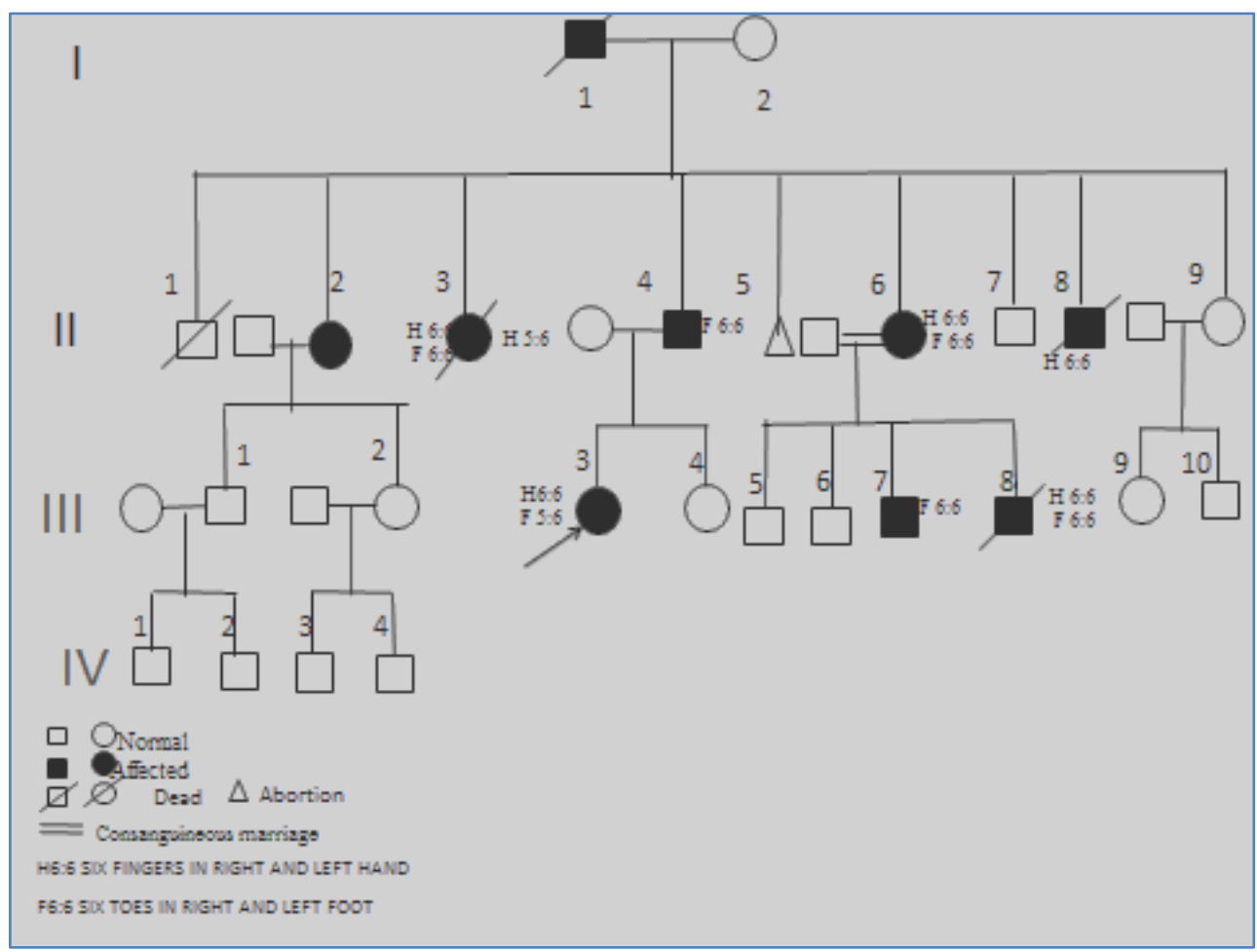

Fig.1:.Pedigree showing AD mode of inheritance of isolated postaxial polydactyly with genetic heterogeneity.

The pedigree shows the presence of male to male transmission in this Egyptian family with affected male: affected female ratio is 5:4 across all studied generations. The disorder is transmitted by both sexes.

Some family members were not affected (I 2,II 1,7,9, III 1,2,4,5,6, ,9,10 and IV 1,2,3,4), the ratio of affected to non-affected individual is $3: 5$

One spontaneous abortion was reported in second generation.

Consanguineous marriage is present in the second generation of this family for member II6 with affected sibling ratio to unaffected of 1:1

Photographs of the available affected members are shown in (Fig.2, 3, 4, 5).
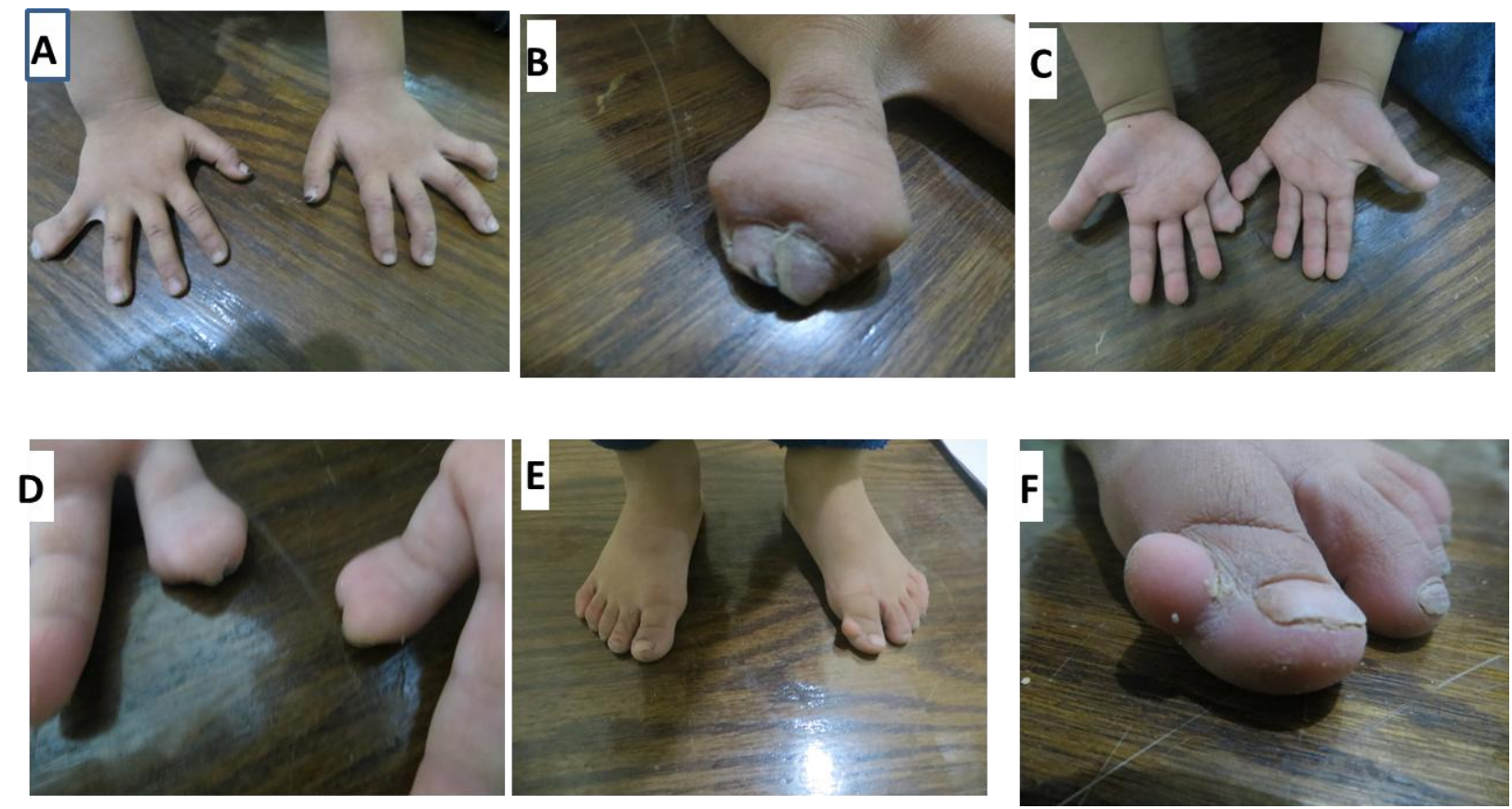

Fig.2: Photographs of proband patient (III3): A, B Bilateral polysyndactyly of upper limbs with distal broadening of terminal phalanges. The nails of polysyndactyly are well developed. C, D are showing palmar creases of hands. E, F are showing left lower limb with preaxial polydactyly type I. 
Citation: Samah Mohammed Mahmoud Abozaid, Polydactyly: A study of a four generation Egyptian family. Australian Journal of Basic and Applied Sciences, 13(1): 104-111. DOI: $10.22587 /$ ajbas.2019.13.1.13
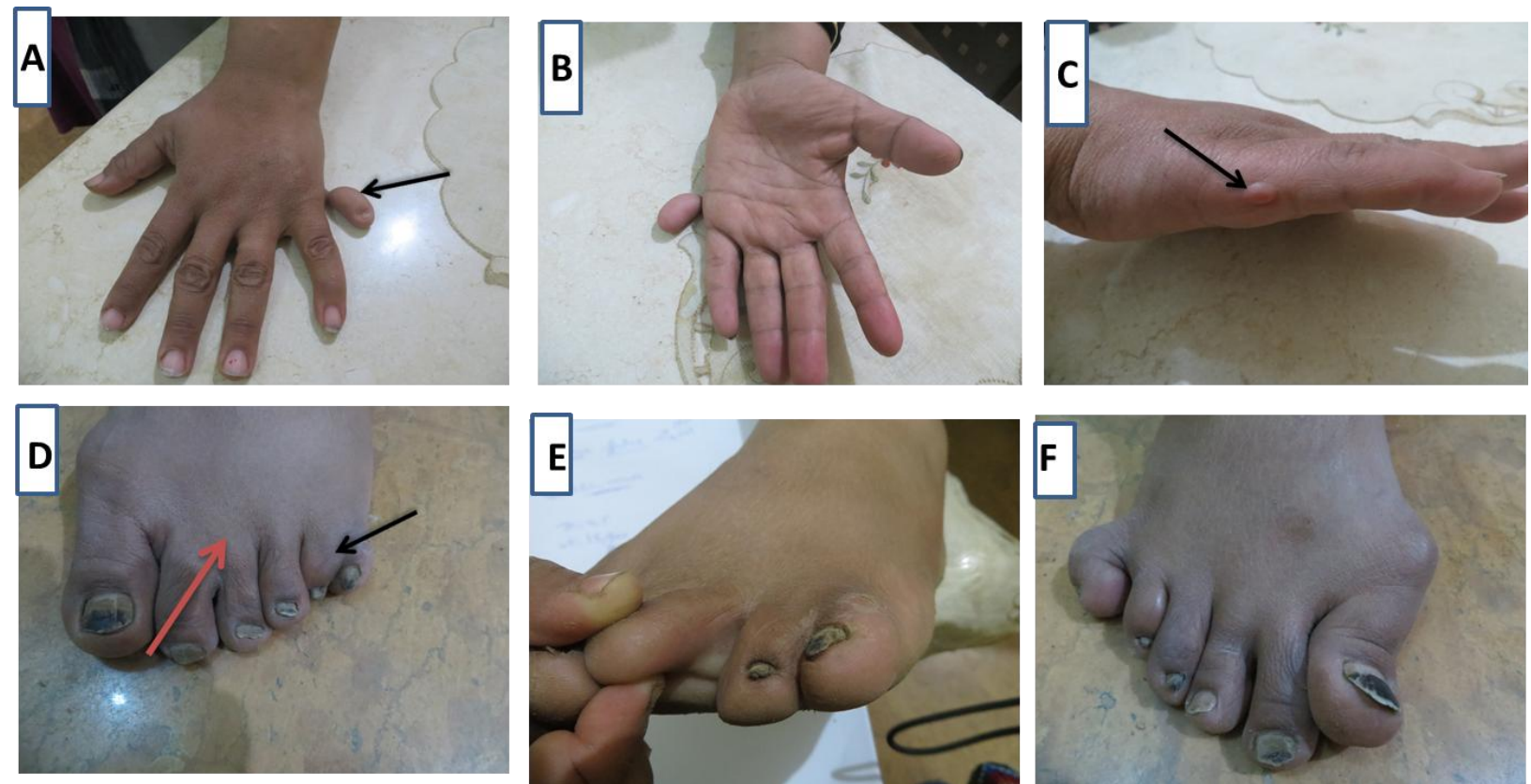

Fig.3: Photographs of patient (II6); A, B show postaxial polydactyly type B of left hand. A show extra digit in dorsum of left hand which has hard element with a well formed nail and attached to the hand at metacarpophalangeal joint of ulnar side by small skin bridge. $\mathrm{C}$ is showing small skin tag. D, E are showing webbing between 2nd and 3rd digits (red arrow) and 5th and 6th digits (black arrow) of left foot. F is showing postaxial polydactyly type A of right foot. Note the angle of articulation of extra digit with the fifth toe
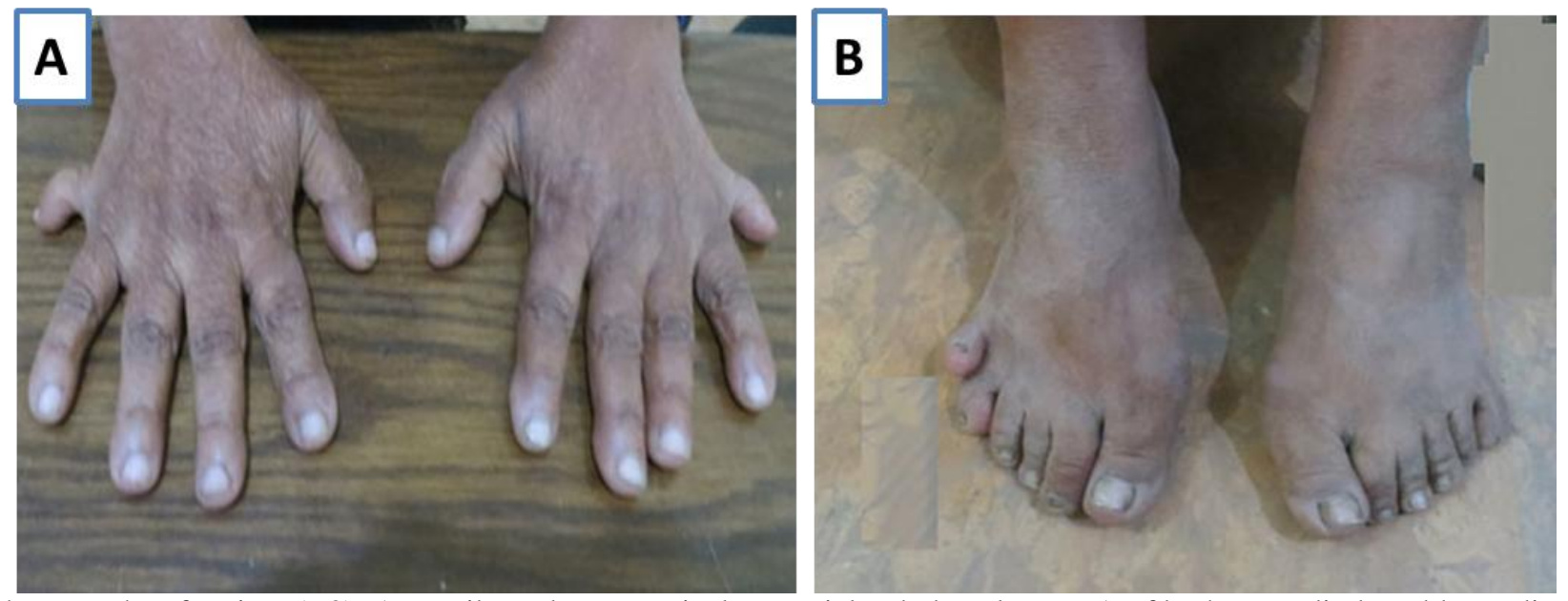

Fig.4: photographs of patient (II2): A, B Bilateral symmetrical postaxial polydactyly type A of both upper limb and lower limb.
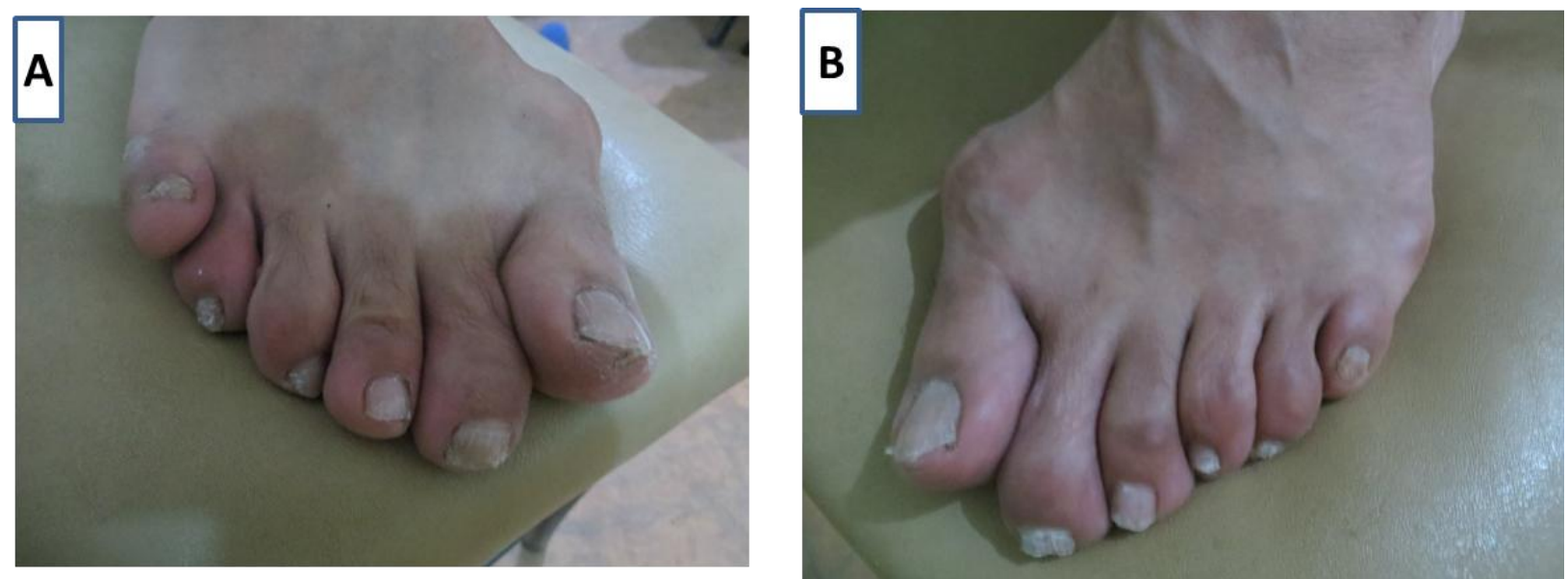

Fig.5: Photographs of patient (II4): A, B Bilateral symmetrical post axial polydactyly type A of both lower limbs. 
Citation: Samah Mohammed Mahmoud Abozaid, Polydactyly: A study of a four generation Egyptian family. Australian Journal of Basic and Applied Sciences, 13(1): 104-111. DOI: 10.22587/ajbas.2019.13.1.13

Table I. Showing limb and side involvement of polydactyly in the affected family members

\begin{tabular}{|c|c|c|c|c|c|}
\hline Pedigree & Sex & Left hand & Right hand & Left foot & Right foot \\
\hline I1 & $\mathrm{M}$ & $\begin{array}{l}\text { Hexadactyly, postaxial } \\
\text { polydactyly type A }\end{array}$ & $\begin{array}{c}\text { Hexadactyly, postaxial } \\
\text { polydactyly type A }\end{array}$ & $\begin{array}{l}\text { Hexadactyly, postaxial } \\
\text { polydactyly } \\
\text { type A }\end{array}$ & $\begin{array}{c}\text { Hexadactyly, postaxial } \\
\text { polydactyly type A }\end{array}$ \\
\hline II 2 & $\mathrm{~F}$ & $\begin{array}{l}\text { Hexadactyly, postaxial } \\
\text { polydactyly type A }\end{array}$ & $\begin{array}{c}\text { Hexadactyly, postaxial } \\
\text { polydactyly type A }\end{array}$ & $\begin{array}{c}\text { Hexadactyly, postaxial } \\
\text { polydactyly } \\
\text { type A }\end{array}$ & $\begin{array}{c}\text { Hexadactyly, postaxial } \\
\text { polydactyly type A }\end{array}$ \\
\hline II3 & $\mathrm{F}$ & $\begin{array}{c}\text { Hexadactyly, postaxial } \\
\text { polydactyly type A }\end{array}$ & Pentadactyly, & Free & Free \\
\hline II4 & M & Free & Free & $\begin{array}{c}\text { Hexadactyly, postaxial } \\
\text { polydactyly type A }\end{array}$ & $\begin{array}{c}\text { Hexadactyly, postaxial } \\
\text { polydactyly type A }\end{array}$ \\
\hline II6 & $\mathrm{F}$ & $\begin{array}{l}\text { Hexadactyly, postaxial } \\
\text { polydactyly type B }\end{array}$ & $\begin{array}{l}\text { Hexadactyly, postaxial } \\
\text { polydactyly type B }\end{array}$ & $\begin{array}{c}\text { Hexadactyly, postaxial } \\
\text { polydactyly type A with } \\
\text { syndactyly }\end{array}$ & $\begin{array}{c}\text { Hexadactyly, postaxial } \\
\text { polydactyly type A }\end{array}$ \\
\hline II8 & M & $\begin{array}{l}\text { Hexadactyly, postaxial } \\
\text { polydactyly type B }\end{array}$ & $\begin{array}{c}\text { Hexadactyly, postaxial } \\
\text { polydactyly type B }\end{array}$ & Free & Free \\
\hline III3 & $\mathrm{F}$ & $\begin{array}{l}\text { Hexadactyly, } \\
\text { Polysyndatyly }\end{array}$ & $\begin{array}{l}\text { Hexadactyly, } \\
\text { Polysyndatyly }\end{array}$ & $\begin{array}{c}\text { Hexadactyly, preaxial } \\
\text { polydactyly type I }\end{array}$ & Free \\
\hline III7 & M & Free & Free & $\begin{array}{c}\text { Hexadactyly, postaxial } \\
\text { polydactyly } \\
\text { type A } \\
\end{array}$ & $\begin{array}{c}\text { Hexadactyly, postaxial } \\
\text { polydactyly type A }\end{array}$ \\
\hline III8 & M & $\begin{array}{l}\text { Hexadactyly, postaxial } \\
\text { polydactyly type A }\end{array}$ & $\begin{array}{c}\text { Hexadactyly, postaxial } \\
\text { polydactyly type A }\end{array}$ & $\begin{array}{c}\text { Hexadactyly, postaxial } \\
\text { polydactyly } \\
\text { type A } \\
\end{array}$ & $\begin{array}{c}\text { Hexadactyly, postaxial } \\
\text { polydactyly type A }\end{array}$ \\
\hline
\end{tabular}

Table II. Showing type, finding of affected members in present study, mode of inheritance and the responsible loci/genes according to OMIM

\begin{tabular}{|c|c|c|c|c|}
\hline OMIM & Types: Symbol & Finding & Inheritance & Locus: Gene \\
\hline 174700 & $\begin{array}{l}\text { Crossed } \\
\text { polydactyly }\end{array}$ & $\begin{array}{l}\text { Crossed type I (postaxial polydactyly in hand and } \\
\text { preaxial in feet) }\end{array}$ & $\mathrm{AD}$ & 7P14.1:GLS;7Q36;ZRS/SHH \\
\hline 174200 & $\begin{array}{c}\text { Postaxial } \\
\text { A1(types } \\
\text { A/B):PAPA1 }\end{array}$ & $\begin{array}{l}\text { Polydactyly of fifth finger or toe; type A; well- } \\
\text { formed articulating digit containing one to three } \\
\text { phalanges; type B; minor protuberance, a knob like } \\
\text { pedunculated postminimi }\end{array}$ & $\mathrm{AD}$ & 7P14.1:GLI3;7Q36;ZRS/SHH \\
\hline 602085 & $\begin{array}{l}\text { Postaxial } \\
\text { A2;PAPA2 }\end{array}$ & Phenotype A, extra digit is well formed & $\mathrm{AD}$ & $13 \mathrm{Q} 21-32$ \\
\hline 607324 & $\begin{array}{l}\text { Postaxial } \\
\text { A3;PAPA3 }\end{array}$ & Phenotype A/B in hands and feet & $\mathrm{AD}$ & 19P13.1-13.2 \\
\hline 608562 & $\begin{array}{l}\text { Postaxial } \\
\text { A4;PAPA4 }\end{array}$ & $\begin{array}{c}\text { Phenotype A/B in hands and feet; two to three } \\
\text { syndactyly }\end{array}$ & $\mathrm{AD}$ & 7Q21-Q34 \\
\hline
\end{tabular}

OMIM= Online Mendelian Inheritance in Man 
Citation: Samah Mohammed Mahmoud Abozaid, Polydactyly: A study of a four generation Egyptian family. Australian Journal of Basic and Applied Sciences, 13(1): 104-111. DOI: $10.22587 /$ ajbas.2019.13.1.13

Table III. Showing affected members segregation per generations, male: female ratio, limb involvement, type of polydactyly and associated anomalies in affected families of different populations

\begin{tabular}{|c|c|c|c|c|c|c|c|c|c|c|c|c|c|c|}
\hline \multirow{3}{*}{ Study } & \multirow{2}{*}{\multicolumn{5}{|c|}{$\begin{array}{c}\text { Affected members } \\
\text { segregation/generations }\end{array}$}} & \multirow{3}{*}{$\begin{array}{l}\text { M:F } \\
\text { ratio }\end{array}$} & \multicolumn{4}{|c|}{ Limb involvement } & \multicolumn{3}{|c|}{ Type of polydactyly } & \multirow{3}{*}{ Associations } \\
\hline & & & & & & & \multicolumn{2}{|c|}{$\begin{array}{l}\text { Upper } \\
\text { limb }\end{array}$} & \multicolumn{2}{|c|}{$\begin{array}{l}\text { Lower } \\
\text { limb }\end{array}$} & \multirow{2}{*}{$\begin{array}{c}\text { Preaxial } \\
\begin{array}{c}\text { All } \\
\text { types }\end{array}\end{array}$} & \multicolumn{2}{|c|}{ Postaxial } & \\
\hline & I & II & III & IV & V & & $\mathbf{L t}$ & Rt & Lt & Rt & & $\begin{array}{c}\text { Type } \\
\text { A }\end{array}$ & $\begin{array}{c}\text { Type } \\
\text { B }\end{array}$ & \\
\hline $\begin{array}{l}\text { (Kucheria } \\
\text { et al., } 1981 \\
\text { (India) }\end{array}$ & 1 & - & 5 & 6 & & $11: 1$ & 12 & 12 & 12 & 12 & No & 23 & 1 & $\begin{array}{l}1 \text { Syndactyly }\left(5^{\text {th }} \text { and } 6^{\text {th }}\right. \\
\text { of Rt hand) } \\
\text { 1Seven fingers right hand }\end{array}$ \\
\hline $\begin{array}{c}\text { Khan, } 2018 \\
\text { (Pakistan) }\end{array}$ & - & 1 & 1 & 1 & 3 & $4: 2$ & 6 & 6 & 6 & 6 & No & 24 & - & $\begin{array}{l}\text { Syndactyly of } 4 \text { th and } 5 \text { th } \\
\text { finger was present in both } \\
\text { hands of all cases. }\end{array}$ \\
\hline $\begin{array}{l}\text { Present } \\
\text { study }\end{array}$ & 1 & 5 & 3 & - & & $5: 4$ & 7 & 6 & 7 & 6 & 1 case & 21 & 4 & $\begin{array}{c}\text { 1bilateral polysyndactyly } \\
\text { of hand } \\
1 \text { unilateral } \\
\text { polysyndactyly of left } \\
\text { foot }\left(2^{\text {nd }} \text { and } 3^{\text {rd }}, 5^{\text {th }} \text { and }\right. \\
\left.6^{\text {th }}\right)\end{array}$ \\
\hline
\end{tabular}

\section{DISCUSSION}

Polydactyly is one of the most common congenital musculoskeletal anomalies. It can occur sporadically but it can also be inherited with mainly autosomal dominant pattern of inheritance (Malik, 2014). Also Abulezz et al., (2016) reported that polydactyly with positive family history have genetic background.

An Egyptian family of four generations is known with inheritance of polydactyly was studied.

The studied polydactyly of the present study is of familial type this is because of bilateral affection and symmetrical presentation of affected members this is in agreement with (Castilla et al., 1973 and Malik, 2014).

The pedigree of this Egyptian family suggested autosomal dominant pattern of inheritance of postaxial polydactyly with variability in penetrance and expression. The autosomal dominant inheritance is indicated by male to male transmission (Khan, 2018), the disorder is transmitted by both sexes, male: female ratio is equal and successive generations are affected (ScottEmuakpor and Madueke, 1976). These findings are present in this family pedigree although there is no reported cases in generation IV this may be due to variable penetrance of the disorder also there are only until now two members in this generation.

This pedigree showed $\mathrm{AD}$ with incomplete penetrance which means that the individual who inherits the mutation will not necessary presented with the trait as in this Egyptian family there were members with apparently normal digits. This is in accordance with (Haber et al., 2007 and Scott-Emuakpor and Madueke, 1976) who reported that postaxial polydactyly showed autosomal dominant inheritance with decreased penetrance (64.9\%).

Polydactyly in this family exhibited PAP type A and B, syndactyly, preaxial polydactyly type I and crossed polydactyly type I and 3 cases were diagnosed with PAP type A of both hands and feet The variable presentation of the affected members with polydactyly in this Egyptian family indicating variable expression this is in agreement with (Stevenson et al., 1993; Ying et al., 2016).

Polydactyly in this family exhibited PAP type A and B this is in agreement with (Malik, 2014 and Ventruto et al., 1980) who stated that studies of various pedigrees with PAP indicate that there are 2 phenotypically different forms. In postaxial polydactyly type A, the extra digit is well formed and articulates with the fifth or an extra metacarpal. This type is inherited as a dominant trait with high penetrance. In postaxial polydactyly type B, also known as pedunculated postminimi, the extra digit is not well formed and is frequently in the form of a skin tag and these findings were consistent with a single dominant gene.

As all cases were presented with type A polydactyly except for one male case was presented with only type B PAP of both hands and a female case was presented with PAP type B of both hands and PAP type A in both feet this suggest high penetrance of type A polydactyly and low penetrance of type B this is in agreement with (Castilla et al., 1997) who reported high penetrance of type A PAP $(\sim 68 \%)$ and low penetrance of type B PAP $(\sim 43)$. This variation in penetrance may be due to presence of inhibiting and modifying genes (Kucheria et al., 1981 and Malik, 2014).

In the present study occurrence of type A and B in the same person and same pedigree was reported. This may suggest a common genetic entity responsible of both types (Woolf and Woolf, 1970). However PAP type A differ from PAP type B in that parents with type A polydactyly can have children with either Type A or B ulnar polydactyly, while children of persons with only Type B can have only Type B polydactyly. Both types are usually inherited as an autosomal dominant and the responsible loci have been identified on chromosomes 7, 13 and 19 (Galjaard et al., 2003).

The occurrence of PAP type B may be due to premature termination resulting in relatively mild phenotype this is may be due to nonsense-mediated mRNA decay that eliminates a toxic dominant-negative effect of a mutant protein (Furniss et al., 2007). 
Three cases out of nine cases (33.3\% of affected cases) in this pedigree exhibited bilateral polydactyly type A in both hands and feet although the occurrence of this pattern is rare as reported by (Castilla et al., 1973 and Neglian, 2013).

Also the occurrence of PAP with polysyndactyly (case II6 and case III3 in the present study) indicated a common causative factor. This is in agreement with (Khan, 2018 and Kucheria et al., 1981) who suggested a common causal factor for postaxial polydactyly types A and B and polysyndactyly, consistent with an autosomal dominant pattern of inheritance.

Male to female ratio in the present study was 5:4 this is in near to ratio reported by Temtamy (1979) who suggested sex ratio of 1M:1F however, Castilla et al., (1973) reported that male to female ratio of 2:1.

Sex of the affected member appeared to have an effect on expressivity of this anomaly (Niha, 2017) as in the present study a female case II6 had asymmetrical PAP type B of both hands and PAP type A of both feet with syndactyly of left foot $\left(2^{\text {nd }}\right.$ and 3 rd, 5th and 6th) also female case III3 who exhibited preaxial polydactyly type I of left foot and bilateral polysyndactyly of hand.

Consanguinity was reported in this family pedigree. The offspring of this consanguineous marriage were $50 \%$ affected this is in agreement with (Abulezz et al., 2016 and Rittler et al., 2001) who reported that parental consanguinity has a significant association with many congenital anomalies as hydrocephalus, postaxial hand and foot polydactyly and bilateral cleft lip / palate.

The present study showed great variable presentation further studies may assess the possible influence of various modifier genes on digits development (Stevenson et al., 1993 and Talamillo et al., 2005).

Case III3 in the present study presented with polysyndactyly of both hands and preaxial polydactyly of left foot and classified as having crossed polydactyly type I this is in agreement with (Temtamy and McKusick, 1978 and Ying et al., 2016) who stated that Crossed polydactyly (CP) indicates the existence of preaxial polydactyly and PAP with different axis of extra digit between the upper limb and lower limb.

In case II6 presented with PAP type B of the hands in the present study may be due to GLI3 gene this is in agreement with Furniss et al., (2007) who reported that the etiology of PAP type B is a heterozygous mutation in the GLI3 gene.

Mutation in ZRS/SHH are identified to be the cause of preaxial type I polydactyly (Lettice et al., 2002). Genetic studies have demonstrated that $\mathrm{CP}$ type $\mathrm{I}$ is allelic to PAP A/B and mutation in GLI3 and ZRS/SHH are the cause of the phenotype (Radhakrishna et al., 1999).

Polydactyly varies between populations as its highly heterogeneous showing wide intra and inter familial variations. This in in agreement with (Malik, 2014 and Stevenson et al., 1993) who stated that the presentation of polydactyly varies according to geographical and racial factors.

The present study suggests autosomal dominance pattern of polydactyly in this affected Egyptian family with high penetrance and variable expressivity. Also the presentation of polydactyly in this Egyptian family varies from other populations indicating high heterogeneity of the disorder.

\section{COMPETING INTERESTS}

The author declares that there was no conflict of interest.

\section{ACKNOWLEDGEMENTS}

The author would like to thank the entire participants for making this study successful.

\section{REFERENCES}

Abulezz, T., M. Talaat, A. Elsani, and K.. Allam, 2016. Congenital hand anomalies in Upper Egypt. Indian J Plast Surg, 49(2): 206-213. doi: 10.4103/0970-0358.191303

Bromley, B., T. Shipp and B. Benacerraf, 2000. Isolated polydactyly: prenatal diagnosis and perinatal outcome. Prenat Diagn, 20:905-908

Castilla, E., J. Paz., O. Mutchinik, E. Munoz, E. Giorgutti and Z.Gelman, 1973. Polydactyly: a genetic study in South America. Am J Hum Genet, 25:405-12.

Castilla, E., R. Lugarihno da Fonseca, M. da Graca Dutra and J. Paz, 1997. Hand and foot postaxial polydactyly: two different traits. Am J Med Genet, 73:48-54

Castilla, E., R. Lugarinho, M. da Graça Dutra and L. Salgado, 1998. Associated anomalies in individuals with polydactyly. Am J Med Genet, 80:459-465.

Furniss, D., P. Critchley, H. Giele and A. Wilkie, 2007. Nonsense-mediated decay and the molecular pathogenesis of mutations in SALL1 and GLI3. Am. J. Med. Genet, 143A: 3150-3160.

Galjaard, R., A. Smits and J.Tuerlings, 2003. A new locus for postaxial polydactyly type A/B on chromosome 7q21-134. European Journal of Human Genetics, 11- 409415

Haber, L., H. Adams, G. Thompson, L. Duncan, L. Didomenico and W. McCluskey, 2007. Unique case of polydactyly and a new classification system. J Pediatr Orthop, 27:326-328.

Hosalkar, H., H. Shah, P. Gujar and A. Kulkarni, 1999. Crossed polydactyly. JPGM, 45(3):90-92

Karaaslan, O., Y. Tiftikcioğlu, H. Aksoy and U. Koçer, 2003. Sporadic familial polydactyly. Genet Couns, 14: 401-405

Khan, M., 2018. Genetic Analysis of Hereditary Polydactyly in Pakistani Families, thesis submitted in partial fulfillment for the degree of Master of Science in the Faculty of Health \& Life Sciences Department of Biosciences, Capital university of science and technology Islamabad. 
Koçer, U., H. Aksoy, Y. Tiftikcioğlu and O. Karaaslan, 2002. Polydactyly: a study of four generations of a Turkish family including an affected member with bilateral cleft lip and palate. Scand J Plast Reconstr Surg Hand Surg, 36: 284-288

Kucheria K., R. Kenue and N. Taneja, 1981. An Indian family with postaxial polydactyly in four generations. Clin Genet, 20(1):36-9.

Lettice, L., T Horikoshi, S. Heaney, M. van Baren, H. van der Linde, J. Breedveld, M. Joosse, N Akarsu et al., 2002. Disruption of a long-range cis-acting regulator for Shh causes preaxial polydactyly. Proc Natl Acad Sci U S A, 99(11):754853.

Malik, S., 2014. Polydactyly: phenotype, genetics and classification. Clinical Genetics, 85:203-212.

Neglian, P., 2013. Plastic Surgery. 3rd ed. Philadelphia: Elsevier, 603-33.

Niha, N., 2017. Polydactyly- A review. International journal of information research and review, 4(7):4302-4305.

Nogami, H., 1986. Polydactyly and polysyndactyly of the fifth toe. Clin. Orthop, 204:261-265

Radhakrishna, U., D. Bornholdt and H. Scott et al., 1999. The phenotypic spectrum of GLI3 morphopathies include autosomal preaxial polydactyly type -IV and postaxial type A/B:No phenotype prediction from the position of GLI3 mutations. Am J Hum Genet, 65(3):645-655.

Rittler, M., R. Liascovich, J. Lopez-Camelo and E. Castilla, 2001. Parental consanguinity in specific types of congenital anomalies. Am. J. Med Genet 2, 102 (1): 36-43.

Scott-Emuakpor, A.B., E.D.N. Madueke., 1976. The study of genetic variation in Nigeria. II. The genetics of polydactyly. Hum. Hered, 26: 198-202.

Stevenson, R.E., J. Hall and R.M. Goodman, 1993. Human malformations and related anomalies. New York: Oxford University Press, p 818-28.

Talamillo, A., M.F. Bastida, M. Fernandez-Teran and M.A. Ros, 2005. The developing limb and the control of the number of digits, Clin. Genet. 67 (2): 143-53

Temtamy, S.A., and V.A. McKusick, 1978. The genetics of hand malformations. Birth Defects Orig Artic Ser, 14(3):1-619.

Temtamy, S. A., 1979. Polydactyly. Birth Defects Compendium, 2nd Ed., ed. Bergsma, D. New York, MacMillan, p. 814.

Ventruto, V., G. Theo, A. Celona, G. Fioretti, L. Pagano, M. Stabile and M.L.A. Cavaliere, 1980. postaxial polydactyly in two members of the same family. Clin. Genet, 18: 342-347

Watson, B.T., and W.L. Hennrikus, 1997. Postaxial type-B polydactyly. Prevalence and treatment. J Bone Joint Surg Am, 79(1):65-8.

Woolf, C.M., and R.M. Woolf, 1970. A genetic study of polydactyly in Utah. Amer. J. hum. Genet, 22, 75-88.

Ying, X., B. Jingxia, W. Zhigang, X. Yunlan and F. Qihua, 2016. Clinical study of 459 polydactyly cases in China, 2010 to 2014. Congenital Anomalies 56, 226-232

Zhou, G.X., L. Dai, J. Zhu, L.Miao, Wang, Y.P. Liang, et al., 2004. Epidemiological analysis of polydactylies in Chinese perinatals. Sichuan Da Xue Xue Bao Yi Xue Ban, 35(5):708-710. 